\title{
JOANNA CZŁOWIEKOWSKA
}

ORCID: 0000-0001-9584-9821

Uniwersytet Jagielloński

joanna.czlowiekowska@uj.edu.pl

\section{O pojęciu i klasyfikacji związków publicznoprawnych}

\begin{abstract}
Abstrakt: Artykuł przedstawia podstawowe założenia koncepcji związków publicznoprawnych Tadeusza Bigi i akcentuje jej aktualność. Koncepcja wskazuje na związek między pojęciami: związki (korporacje) publicznoprawne, samorząd, decentralizacja.
\end{abstract}

Słowa kluczowe: związek publicznoprawny, korporacja prawa publicznego, samorząd, samorząd terytorialny, decentralizacja.

Niniejszy artykuł ma na celu przedstawienie podstawowych aspektów koncepcji Profesora Tadeusza Bigi opisanej w monografii Zwiazki publiczno-prawne $w$ świetle ustawodawstwa polskiego ${ }^{1}$ i wskazać na jej aktualność oraz potrzebę badań w obszarze związków (korporacji) publicznoprawnych.

Zacząć należy od tego, że punktem wyjścia do rozważań Tadeusza Bigi nad związkami publicznoprawnymi było mierzenie się z „odwiecznym” problemem dualizmu prawa, jego podziału na prawo publiczne i prywatne. Jak wskazywał, określenie „,związek publicznoprawny”" można ująć pojęciowo tylko drogą zróżnicowania cząstki „,związek” na dwa gatunkowo odrębne terminy: związek publiczny (publicznoprawny) oraz związek prywatny (prywatnoprawny) ${ }^{3}$. Bigo stawia hipotezę o dualizmie polskiego systemu i istnieniu tendencji do przeprowadzania

1 T. Bigo, Związi publiczno-prawne w świetle ustawodawstwa polskiego, Warszawa 1928, reprint w I Serii Klasyki Samorządowej — Warszawa 1990.

2 Pisownia przymiotnika ,publicznoprawny” zmieniała się na przestrzeni dziejów. W czasie działalności Tadeusza Bigi przymiotnik ten pisano z łącznikiem: „publiczno-prawny”. Aktualnie zasady pisowni nakazują pisownię łączną.

3 Ibidem, s. 1. 
linii demarkacyjnej między obydwoma działami prawa mniej więcej w ten sam sposób, co w systemie niemieckim. Jej sprawdzenie, zdaniem badacza, wymagało przeanalizowania całego ustawodawstwa polskiego metodą indukcji, w wyniku czego można by ustalić taką linię i pokusić się o syntezę, czyli wskazanie kryterium $^{4}$. Jako zadanie dla dalszej części rozważań wskazuje „przeprowadzić próbę rozgraniczenia prawa prywatnego od publicznego na jednym, małym odcinku: korporacyj" ", precyzując, że chodzi o zbadanie natury prawnej korporacji nazwanych przez ustawodawcę publicznymi i w czym ona się przejawia.

Tytuł monografii nie pozostawia wątpliwości, że podstawowym stosowanym przez Bigę określeniem jest „związek publiczno-prawny”. Autor posługuje się jednak równorzędnie pojęciem korporacji publicznej ${ }^{6}$. To określenie przeważa obecnie w nauce prawa administracyjnego. Rozumie się pod nim „organizacyjnie wyodrębnione i uporządkowane zrzeszenie osób fizycznych wyróżnionych w oparciu o kryterium wykonywania zawodu, kryterium zamieszkania czy inne kryterium (kryteria), które na podstawie uregulowań ustawowych lub w obrębie okoliczności prawnie określonych jest zdolne przez tworzone przez siebie organy do podejmowania czynności prawnych i aktów o charakterze publicznoprawnym wobec własnych członków w zakresie dysponowania własnym majątkiem lub własnym władztwem lub także wobec innych podmiotów w określonych sytuacjach, wyłączonych niekiedy spod kontroli sądowej”"7. Według innego poglądu, korporacja stanowi organizacyjnie uporządkowane zrzeszenie osób, które na mocy przypisania jest zdolne do objawiania woli i podejmowania czynności prawnych, istniejące niezależnie od zmiany poszczególnych członków. Członkowie korporacji są nie tylko uprawnieni, ale i zobowiązani do udziału w jej samourzeczywistnianiu i realizacji jej celów ${ }^{8}$.

Wypada również podkreślić stanowisko Bigi odnośnie do problemu osobowości publicznoprawnej, które sam określa jako negatywne. Sprowadza się ono do tego, że — zdaniem Bigi — osobowość prawna jest jedna na całym obszarze prawa i oznacza zdolność stawania się podmiotem praw i obowiązków. Jak wskazuje: „Pewne organizacje prawne, posiadające osobowość prawną, mogą zajmować szczególne stanowisko w państwie (np. zakłady samoistne, związku publ.-prawne). Uzasadnienia tej odrębności nie można jednak szukać w samej istocie osobowości prawnej; ta zawsze jest jednakowa" ".

Przyglądając się samej istocie związku publiczno-prawnego, Bigo wychodzi z założenia, że problematyka tego rodzaju związków może być przedmiotem analizy wyłącznie z punktu widzenia prawa pozytywnego, a nie teoretycznego.

\footnotetext{
4 Ibidem, s. 25.

5 Ibidem, s. 26.

6 Ibidem.

7 J. Boć, Prawniczy słownik wyrazów trudnych, Wrocław 2005, s. 194.

8 S. Fundowicz, Decentralizacja administracji publicznej w Polsce, Lublin 2005, s. 34 n.

9 T. Bigo, Związi publiczno-prawne...
} 
W jego ocenie istnienie samego problemu zależy od tego, czy ustawodawstwo zna omawianą instytucję $e^{10}$.

Zauważyć należy przy tym, że w czasach współczesnych Uczonemu, w szczególności w czasie powstania rzeczonej monografii, pojęcie związku publicznoprawnego było pojęciem prawnym, nie tylko prawniczym. Wyraźne odniesienia do związków publicznoprawnych zawierała nawet ówczesna Konstytucja ${ }^{11}$. Wskazać tu można art. 109, stanowiący, że w drodze osobnych ustaw państwowych zabezpieczony zostanie mniejszościom narodowym „w Państwie Polskim pełny i swobodny rozwój ich właściwości narodowościowych przy pomocy autonomicznych związków mniejszości o charakterze publiczno-prawnym w obrębie związków samorządu powszechnego". O publicznoprawnym charakterze związków samorządu wojewódzkiego, powiatowego i gminnego stanowił art. 65 ust. 4, w kontekście możliwego nadania takim związkom, w drodze ustawy, osobowości publicznoprawnej.

O pozytywnoprawnych odniesieniach pisze Bigo, używając najbardziej dobitnych przykładów przepisów, w których ustawodawca używał określenia „związek publicznoprawny” oraz nazw zbliżonych, takich jak: „osoba publicznoprawna”, ,instytucja publicznoprawna”, uznając je za terminy o szerszym zakresie niż związek (korporacja) ${ }^{12}$. Bigo wskazuje wiele regulacji posługujących się wprost określeniem „osoba publicznoprawna”, „związek publicznoprawny”, „korporacja prawa publicznego" (publicznoprawna), czy też „instytucja publiczna”13. Z przywołanych przepisów Bigo wyprowadza następujące wnioski: „1) Związki samorządowe są osobami (związkami) publ.-prawnemi, 2) Związki samorządowe nie wyczerpują zakresu związków publ.-prawnych [...], 3) »Samorządy« i »zw. Samorządowe« to są nazwy zw. sam. terytorialnego, 4) „Samorządy” terytorialne inaczej nazywane są związkami komunalnemi”. Wniosków tych Autor nie uznawał jednak za szczególnie istotne, określając je „subsydiarnymi”14.

Drogą, którą obrał Bigo dla ustalenia kryteriów wyodrębnienia związków publicznoprawnych, przeciwstawnych związkom o charakterze prywatnym, była analiza przepisów ustawowych normujących działalność związków nazwanych przez ustawodawcę ,publiczno-prawnymi”.

Bigo zauważa, że przeanalizowane przez niego związki wykazują „wybitne odrębności" pod trzema względami: sposobu powstania i członkostwa, stosunku do państwa, środków działania. Zaliczył więc związki publicznoprawne do organizacji przymusowych w tym sensie, że ich powstanie nie zależy od woli członków albo przynajmniej nie zależy od niej w pierwszym rzędzie, a przynależność

${ }^{10}$ Ibidem, s. 51.

11 Zob. art. 65 ustawy z dnia 17 marca 1921 roku Konstytucja Rzeczypospolitej Polskiej (Dz.U. z 1921 r. Nr 44, poz. 267).

12 T. Bigo, op. cit., s. 52.

13 Ibidem, s. 52-55.

14 Ibidem, s. 55. 
do związku zależy od pewnego, określonego w ustawie, stanu faktycznego, z wyjątkiem związków międzykomunalnych powstających na drodze dobrowolnego porozumienia. Dalej, autor dopatruje się odrębności w nadzorze państwa nad tymi związkami. Nie jest on jedynie tak zwanym nadzorem policyjnym, lecz obejmuje środki o charakterze pozytywnym, w tym: rozwiązywanie organów związku, ustanawianie zastępczych, komisarycznych zarządów, zatwierdzanie uchwał, przymusowe wykonanie zadań związku. Wreszcie Bigo dostrzega, że środki działania tych związków wykazują „,uderzające różnice w stosunku do prywatnych korporacyj”, akty organów związkowych mogą być bowiem wykonywane bez pośrednictwa drogi sądowej, a nawet bez użycia przymusu administracyjnego; władza związku przekracza granice zwykłej władzy korporacyjnej, dyscyplinarnej, a w pewnych wypadkach obejmuje także osoby trzecie (nieczłonków) ${ }^{15}$. Analizując te cechy w odniesieniu do związków publicznoprawnych, dochodzi jednak do przekonania, że tylko dwie spośród nich mogą stanowić o ich wyodrębnieniu, co prowadzi do konkluzji, zgodnie z którą związek publicznoprawny to związek uposażony we władztwo administracyjne, to jest uprawnienie do stosowania przy realizacji swych aktów przymusu, bez pośrednictwa sądów, i powołany do życia przez państwo względnie przy jego czynnym współudziale ${ }^{16}$.

Przedstawione rozważania doprowadziły Bigę do punktu, w którym stwierdził, że oprócz odróżnienia związków publicznoprawnych od związków prywatnoprawnych konieczne jest dostrzeżenie, że związki publicznoprawne (w przeciwieństwie do związków prywatnoprawnych) operują środkami działania właściwymi organom państwa. Działania organów administracyjnych państwa i działalność związków publicznoprawnych postawił tym samym na jednej płaszczyźnie, przypisując im wspólną cechę — działalność polegającą na administracji publicznej. Określa ją jako działalność państwa (z wyłączeniem wymiaru sprawiedliwości i ustawodawstwa) polegającą na realizowaniu prawa przy pomocy przymusu bezpośredniego (sankcji stosowanych bez ingerencji sądów). Konieczne zatem okazało się odróżnienie omawianych związków od organów administracji państwowej. Zdaniem Bigi cel ten byłby możliwy do osiągnięcia tylko wówczas, gdy wyjaśni się, na czym polega decentralizacja administracji ${ }^{17}$. Tę zaś utożsamił z samorządem, którego samodzielnymi podmiotami są korporacje. Wskazał przy tym, że „samorząd jest oznaczeniem formy administracji, wyraża stosunek osób administrujących do państwa, określa tylko jedną relację podmiotu administracji. Związek publ.prawny jest oznaczeniem samego podmiotu administracji"18.

Co do analizowanych związków publicznoprawnych, Bigo wyróżnił typy związków, które uczynił przedmiotem szczegółowej analizy i które posłużyły do wyprowadzenia powyższych wniosków. Do tej grupy zaliczył następujące związ-

15 Ibidem, s. 76-77.

16 Ibidem, s. 82.

17 Ibidem, s. 118-119.

18 Ibidem, s. 115. 
ki: 1) gmina miejska i związek powiatowy, 2) izby przemysłowo-handlowe, 3) żydowski związek religijny, 4) związki jednostek samorządowych, 5) zakłady ubezpieczeń pracowników umysłowych i związek zakładów, 6) izby rolnicze, 7) związki mniejszości. Przepisy te grupuje według istotnych zagadnień: 1) sposób powstania i rozwiązania związku, 2) przynależność do związku, 3) organa związku, 4) stosunek do państwa, 5) środki działania (w szczególności stosunek związku do członków) ${ }^{19}$. Oprócz wymienionych typów Bigo poddał analizie, ze względu na kryterium władztwa administracyjnego, inne podmioty o charakterze korporacyjnym w celu zweryfikowania zakresu badanej instytucji w polskim ustawodawstwie. W tej grupie znalazły się: kasy chorych, korporacje przemysłowe i cechy, izby rękodzielnicze, izba rolnicza śląska, izby lekarskie i naczelna izba lekarska, izby adwokackie, spółki wodne, spółki drogowe, spółki łowieckie, związki samorządu wojewódzkiego, wyznaniowe gminy żydowskie ${ }^{20}$. Nie wszystkie jednak spośród analizowanych podmiotów przeszły pomyślnie test władztwa.

Trudno przecenić znaczenie koncepcji związków publicznoprawnych T. Bigi, uznawanego za „ojca samorządu terytorialnego”. Trwale wpłynęła na pokolenia administratywistów i naukę prawa administracyjnego, szczególnie w zakresie, $\mathrm{w}$ jakim problematyka związków publicznoprawnych związana jest $\mathrm{z}$ decentralizacją władzy publicznej w Polsce. Zainteresowanie tą tematyką, tak jak i samą monografią Bigi, uległo wzmożeniu wraz ze zmianami ustrojowymi rozpoczętymi w 1989 roku. Szczególne oddziaływanie i przemożny wpływ koncepcji Bigi widoczny jest w pracach autorów podejmujących zagadnienia podmiotowości publicznoprawnej, decentralizacji i samorządu terytorialnego, ostatnio między innymi w publikacjach Iwony Skrzydło-Niżnik ${ }^{21}$, Sławomira Fundowicza ${ }^{22}$, Jerzego Korczaka $^{23}$, Ireny Lipowicz ${ }^{24}$.

Warto, za Lipowicz, zwrócić uwagę na jeden z aspektów oddziaływania koncepcji Bigi, pomimo odmiennych uwarunkowań prawnoustrojowych i historycznych:

prace Tadeusza Bigo o samorządzie, powstające na przełomie lat 20. i 30., w epoce nagłego, niemal powszechnego deprecjonowania samorządu w literaturze zachodnioeuropejskiej i równoczesnego odrzucania samorządu jako „burżuazyjnej idei” w komunistycznej Rosji, cechuje konsekwentne podnoszenie demokratycznych wartości samorządu, użyteczności teoretycznej i praktycznej zarówno pojęcia, jak i instytucji samorządu - w czasie, gdy wielu przepowiadało jego rychłą zagładę. Należy docenić taką suwerenność intelektualną polskiej doktryny, zachowującą dystans i krytycyzm

19 Ibidem, s. 56.

20 Ibidem, s. 95.

21 I. Skrzydło-Niżnik, Model ustroju samorzadu terytorialnego w Polsce na tle zagadnień ustrojowego prawa administracyjnego, Kraków 2007.

22 S. Fundowicz, op. cit.

23 J. Korczak, Konstytucyjne podstawy struktury i funkcji samorzadu terytorialnego, [w:] System Prawa Administracyjnego, t. 2. Konstytucyjne podstawy funkcjonowania administracji publicznej, zob. R. Hauser, Z. Niewiadomski, A. Wróbel, Warszawa 2012.

24 I. Lipowicz, Samorzad terytorialny XXI wieku, Warszawa 2019. 
wobec działań ustawodawcy lat 30. Tadeusz Bigo do końca bronił idei samorządowej, próbując nawet konstytucję kwietniową interpretować prosamorządowo ${ }^{25}$.

Akcentowany przez Lipowicz szczególny związek w poglądach Bigi samorządu i demokracji pozostaje aktualny, a nawet — rzec by można — staje się coraz wyraźniej aktualny w momencie, w którym w prawie krajowym widać coraz mocniejsze tendencje centralizacyjne, w którym coraz częściej kwestionuje się ideę decentralizacji oraz samorządu, w szczególności samorządu terytorialnego, stawianego w opozycji do władzy centralnej. Poglądy prof. Tadeusza Bigi powinny stanowić impuls do pogłębionych badań nie tylko nad samorządem terytorialnym, lecz również nad innymi rodzajami korporacji publicznoprawnych stojących na uboczu głównych nurtów badawczych, a także ich klasyfikowania, po to, by — jak chciał Bigo — dobrze poznać istotę zjawiska.

\title{
Bibliografia
}

Bigo T., Zwiazki publiczno-prawne w świetle ustawodawstwa polskiego, Warszawa 1990.

Fundowicz S., Decentralizacja administracji publicznej w Polsce, Lublin 2005.

Korczak J., Konstytucyjne podstawy struktury i funkcji samorzadu terytorialnego, [w:] System Prawa Administracyjnego, t. 2. Konstytucyjne podstawy funkcjonowania administracji publicznej, red. R. Hauser, Z. Niewiadomski, A. Wróbel, Warszawa 2012.

Lipowicz I., Samorzad terytorialny XXI, Warszawa 2019.

Skrzydło-Niżnik I., Model ustroju samorządu terytorialnego w Polsce na tle zagadnień ustrojowego prawa administracyjnego, Kraków 2007.

\section{The Concept and the Classification of Public Law Associations}

\author{
Summary
}

The article presents the basic assumptions of the public law associations concept by Tadeusz Bigo and emphasizes its timeliness. The concept indicates relations between three notions: public law associations (corporations), self-government, and decentralization.

Keywords: public law association, public law corporation, self-government, decentralization.

25 Ibidem, s. 54-55. 